\title{
Peningkatan Kualitas Sari Buah Naga Super Red (Hylocereus Costaricencis) Melalui Introduksi Teknik Ekstrasi dan Aplikasi Enzim Pektinase di Desa Krikilan, Masaran, Sragen, Jawa Tengah
}

\author{
Esti Widowati ${ }^{1 *}$, Bambang Sigit Amanto ${ }^{1}$ \\ ${ }^{1}$ Program Studi Ilmu Teknologi Pangan \\ Fakultas Pertanian Universitas Sebelas Maret Surakarta \\ *Corresponding Author: estiwidowati@staff.uns.ac.id
}

\begin{abstract}
ABSTRAK
Kegiatan ini merupakan bentuk kerjasama lanjutan dengan Kelompok Tani Wana Bekti dan UKM Wana Bekti Handayani di Masaran Sragen Jawa Tengah. Permasalahan yang dihadapi mitra terkait produk sari buah naga super red adalah diperlukannya teknologi untuk memperbaiki kualitas sari buah yang cenderung memisah selama penyimpanan walaupun sudah melalui proses peyaringan. Daya jual produk ini menjadi rendah dan bukan menjadi produk utama UKM karena konsumen yang menganggap produk ini tidak layak konsumsi jika memisah secara visual. Oleh karena itu sebagai solusi aplikatif terhadap masalah tersebut, kegiatan ini mengintroduksikan teknologi ekstraksi sari buah dan aplikasi enzim pektinase yaitu poligalakturonase $0,1 \%$ yang mampu mengklarifikasi sari buah sehingga mempertahankan tekstur sari buah tampak homogen. Dampak langsung mitra adalah produk sari buah semakin berkualitas sehingga meningkatkan daya jual produk tersebut.
\end{abstract}

Kata kunci : buah naga super red, ekstraksi, enzim pektinase, introduksi, sari buah

\begin{abstract}
This activity was a collaboration with the Wana Bekti Farmers Group and Wana Bekti Handayani Small Medium Enterprise (SME) in Masaran Sragen, Central Java. They have problem with super red dragon fruit juice products. They need technology to improve the quality of juice that tends to separate during storage even though it has been through a screening process. The selling power of this product was low and not became the main product of Wana Bekti Handayani SME because the consumers consider this product unfit for consumption if visually separated. Therefore, as an applicable solution to this problem, this activity introduces the extraction technology and the application of the enzyme pectinase, namely polygallacturonase $0.1 \%$ which able to clarify the juice so it can maintain the texture of the juice looks homogeneous. The direct impact was the increasing of the quality of the juice products, thereby increasing the selling power of the product.
\end{abstract}

Keywords: super red dragon fruit, extraction, pectinase enzyme, introduction, fruit juice

\section{PENDAHULUAN}

Menurut Kristanto (2008), buah naga merupakan salah satu buah eksotik yang populer di Indonesia. Buah naga tergolong buah batu yang berdaging dan berair. Bentuk buah bulat agak memanjang atau bulat agak lonjong. Kulit buah ada yang berwarna merah menyala, merah gelap, dan kuning, tergantung dari jenisnya. Kulit buah agak tebal sekitar 3-4 mm. Di sekujur kulitnya dihiasi dengan jumbai-jumbai menyerupai sisik- sisik ular naga. Oleh karena itu, buahnya disebut buah naga. Berat buah beragam berkisar antara 80-500 gram, tergantung dari jenisnya. Daging buah berserat sangat halus dan di dalam daging buah bertebaran biji-biji hitam yang sangat banyak dan berukuran sangat kecil. Daging buah ada yang berwarna merah, putih, dan hitam, tergantung dari jenisnya. Daging buah bertekstur lunak dan rasanya manis sedikit masam (Cahyono, 2009). Kandungan 
komponen fungsional yang sangat menonjol dalam buah naga ialah senyawa antioksidan yang mampu mencegah berbagai penyakit degeneratif.

Senyawa tersebut antara lain phytoalbumin, anthocyanin, vitamin $\mathrm{C}$ dan $\mathrm{E}$, flavonoid dan fenol. Senyawa tersebut dapat dikelompokkan menjadi 3 jenis antioksidan yaitu protector antioxidant (vitamin $\mathrm{C}$, flavonoid), builder antioxidant (anthocyanin) dan fighter antioxidant (phytoalbumin) dalam produk sehingga akan memberikan efek positif bagi selain pektin sebagai serat pangan (Pratomo, 2008; Jacobs, 1999). Oleh karena itu, buah naga merupakan sumber antioksidan dan sumber serat. Dengan prospek dan harga jual yang menjanjikan, saat ini petani di Sragen dan sekitarnya berminat untuk mengembangkan buah naga secara besar-besaran.

Kegiatan ini merupakan kegiatan yang bekerjasama dengan UKM Wana Bekti Handayani yang bergerak di bidang agroindustri dan agronomi sebagai petani dan supplier komoditas buah naga segar. CV Wana Bekti Handayani didirikan sejak tahun 2006 oleh Bapak Ir.Warjimin di lahan seluas $5000 \mathrm{~m}^{2} \mathrm{di}$ Dukuh Prampalan RT 26 RW 06 Desa Krikilan Kecamatan Masaran Kabupaten Sragen Provinsi Jawa Tengah.

Pengembangan komoditas buah ini terfokus pada buah naga jenis super red (Hylocereus costaricensis) atau buah naga super merah (merah hati) dan buah naga daging putih yang masih dikembangkan untuk peningkatan produksi. Kegiatan ini juga bekerjasama dengan kelompok tani buah naga Wana Bekti yang merupakan perkumpulan para petani yang bergerak di bidang agribisnis buah naga di daerah Masaran Sragen Jawa Tengah. Kelompok Tani ini dirintis sejak tahun 2006, dengan ketua Ibu Sri Subekti, membawahi 12 pengusaha tani. Sampai saat ini kebun buah naga yang dikelola seluas 5,22 hektar.

Masalah kenampakan tekstur sari buah naga super red yang cenderung memisah selama penyimpanan membuat sari buah bukan menjadi produk unggulan dan daya jualnya rendah karena konsumen menganggap produk telah rusak jika kenampakannya telah memisah. Oleh karena itu, tujuan kegiatan ini adalah untuk memperoleh produk sari buah naga super red dengan tekstur yang homogen dengan aplikasi enzim pektinase (poligalakturonase) $0,1 \%$.

\section{METODE}

Kegiatan ini didahului oleh kegiatan sosialisasi proposal kegiatan oleh tim untuk menentukan solusi dari permasalahan sari buah tersebut bersama Kelompok Tani Buah Naga SuperRed (Hylocereus costaricensis) Wana Bekti dan UKM Wana Bekti Handayani. Kegiatan ini dilaksanakan untuk memfokuskan permasalahan dan solusi tepat yang berkaitan dengan memperbaiki kualitas sari buah naga super red.

Hasil identifikasi menunjukkan bahwa perlu ada perbaikan teknik ekstraksi untuk menghasilkan sari buah yang lebih berkualitas dan solusi tepat supaya sari buah tidak memisah kembali setelah dilakukan filtrasi. Berdasarkan kebutuhan yang berhasil diidentifikasi selanjutnya diterapkan program introduksi dan pelatihan teknik ekstraksi sari buah dan aplikasi penggunaan enzim pektinase yaitu poligalakturonase $0,1 \%$. Enzim ini merupakan hasil penelitian oleh tim yang dipurifikasi parsial dari bakteri Bacillus licheniformis strain GD2A AR2.

Dalam kegiatan ini, UKM Wana Bekti Handayani berpartisipasi aktif sebagai penyedia bahan pembantu dalam pembuatan sari buah naga super red dan keperluan lain yang secara teknis membantu dalam kegiatan pelatihan teknik ekstraksi dan aplikasi enzim dalam pembuatan sari buah naga super red. Kelompok Tani Wana Bekti berperan menyediakan buah naga super red sebagai bahan baku utama. Selanjutnya dengan pembinaan Tim Kelompok Tani Wana Bekti dan UKM Wana Bekti Handayani melaksanakan kegiatan produksi dan pemasaran sari buah naga super red. Diharapkan setelah pendampingan, Kelompok Tani Wana Bekti dan UKM Wana Bekti Handayani dapat menjadi produsen sari buah naga super red yang mandiri dan memiliki kualifikasi.

\section{HASIL DAN PEMBAHASAN}

Kegiatan pengabdian kepada masyarakat ini mengintroduksikan teknologi pembuatan sari buah naga super red. Produk ini memanfaatkan daging buah naga super red terutama buah yang secara ekonomi tidak disukai untuk konsumsi segar. Setelah tahapan sortasi dan penimbangan selanjutnya dilakukan pengirisan dan pengekstrakkan menggunakan juicer sampai diperoleh sari buah dan ampas. Sari buah kemudian dipanaskan kemudian ditambah bahan 
tambahan seperti asam sitrat dan asam benzoat kemudian siap dikemas ke dalam kemasan botol kaca atau gelas plastik setelah dipasteurisasi dan didinginkan. Enzim diaplikasikan sebelum tahap pasteurisasi. Inkubasi dilakukan selama 30 menit untuk membantu proses klarifikasi sari buah oleh enzim.

Produksi sari buah naga super red milik UKM CV Wana Bekti Handayani memiliki kendala yaitu sari buah yang memisah selama penyimpanan walaupun telah mengalami proses penyaringan. Sari buah dengan kondisi seperti itu dapat membuat persepsi negatif dari konsumen bahwa sari buah sudah tidak layak konsumsi. Solusi untuk masalah tersebut adalah klarifikasi atau penjernihan sari buah. Klarifikasi akan mengurangi viskositas dan mengingkatkan kecerahan sari buah. Tim pengabdian mengaplikasikan enzim poligalaturonase (PG) untuk mengatasi masalah dalam klarifikasi tersebut. Aplikasi tersebut merupakan hasil penelitian tim peneliti pada tahun 2012-2016.

Selain itu, untuk mengatasi masalah kurangnya alat dalam proses ekstraksi sari buah maka perlu ditambah juicer yang dilengkapi penyaring khusus untuk sari buah naga. Karakter buah naga yang diekstraksi beserta dengan bijinya dapat menyulitkan membran filtrasi sehingga hancuran biji dapat terikut dalam sari buah dan mengganggu secara visual. Proses filling sari buah dapat dibantu juga dengan panci kran yang telah dilengkapi penyaring sehingga sari buah tersaring sekaligus dapat langsung dimasukkan ke dalam kemasan.

Masalah lainnya adalah keamanan produk sari buah dan minuman fermentasi buah naga (Minaga) dalam kemasan botol (produk UKM selain sari buah). Setelah proses pembotolan kemudian dilakukan pasteurisasi yang diharapkan dapat membunuh mikroorganisme perusak. Kondisi pasteurisasi yang tepat dapat memaksimalkan hasil sehingga produk menjadi lebih aman konsumsi. Introduksi alat pengukus yang dilengkapi penyangga botol dapat membantu proses ini sekaligus dapat mempercepat proses pasteurisasi karena sekaligus dapat digunakan untuk 10 botol sekali proses. Botol yang telah kering kemudian dibungkus plastik untuk mempertahankan keamanan produk dari cemaran dan mempercantik tampilan produk.

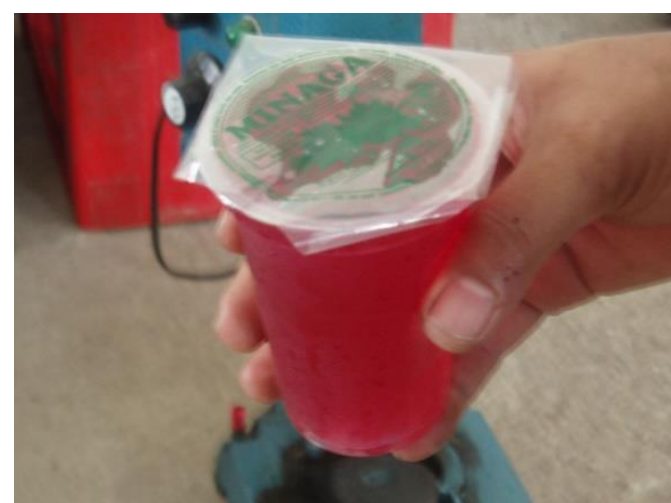

(a)

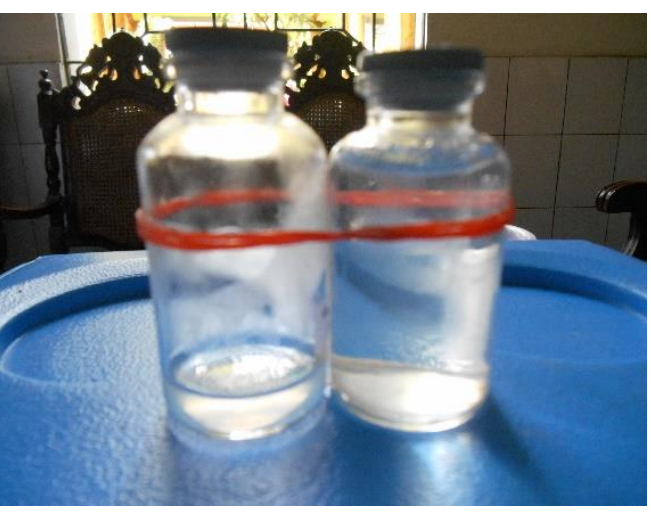

(b)

Gambar 1. (a) Produk Sari Buah Naga Super Red, (b) Enzim Poligalakturonase Murni Parsial 0,1\%

Sari buah naga yang juga dikemas dengan kemasan cup plastik dibantu dengan introduksi alat cup sealer semi otomatis sehingga produk menjadi lebih aman dan proses menjadi lebih cepat. Introduksi cup sealer juga dilakukan untuk mengatasi masalah kebocoran pada produk sari buah dalam kemasan gelas plastik. Selain itu untuk mempercepat proses pengemasan karena ketersediaan alat pengemas yang lebih. Gambar sari buah dalam kemasan cup dan enzim poligalakturonase dapat dilihat pada gambar 1. Introduksi lainnya adalah alat juicer, dandang pasteurisasi dan penyaring lengkap dengan kran dan panci. Alat ini mempercepat proses ekstraksi, pasteurisasi dan filtrasi sehingga ikut memperbaiki mutu dan menurunkan resiko kerusakan produk selama proses. Kapasitas produksi untuk sari buah naga super red ini adalah dalam setahun membutuhkan $6.886 \mathrm{Kg}$ buah yang dapat menghasilkan 173 galon produk untuk dikemas dalam 8.650 botol kemasan.

\section{KESIMPULAN}

Kegiatan ini mengintroduksikan teknologi pembuatan sari buah dalam kemasan cup plastik dan intoduksi alat cup sealer. Introduksi tersebut 
mampu mengatasi masalah mitra yaitu kebocoran pada kemasan produk secara keseluruhan, memudahkan distribusi dan meningkatkan kualitas produk. Aplikasi enzim poligalakturonase Teknologi produksi sari buah naga super red tersebut mengatasi masalah buah naga super red yang harganya cenderung turun akibat overproduksi saat panen sehingga menguntungkan petani dan memperpanjang umur simpan. Bagi kabupaten Sragen, produk tersebut dapat menadi produk unggulan daerah. Manajemen pemasaran produk olahan buah naga super Red ini terbantu dengan telah dimilikinya $\mathrm{P}$ IRT dan leaflet untuk memperluas jaringan pemasaran dan kerjasama.

\section{DAFTAR PUSTAKA}

Cahyono B. 2009. Buku Terlengkap Sukses Bertanam Buah Naga. Pustaka Mina. Jakarta.

Kristanto D. 2008. Buah Naga : Pembudidayaan di Pot dan di Kebun. Penebar Swadaya. Jakarta.

Pratomo. 2008. Superioritas Jambu Biji dan Buah Naga. http://www.unika.ac.id/pasca/pmpt/?p=5 (Diakses pada tanggal 12 Agustus 2016). 